\title{
Vantržišna motivacija tržišta umetničkih dela
}

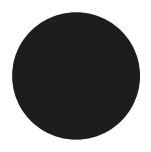

\section{. \\ Non-Market \\ Motivation of the Art Market}


PRETHODNO PRIOPĆENJE

Predan: 18.2.2019.

Prihvaćen: 4.4.2019.

DOI: $10.31664 / z u .2019 .104 .04$

UDK: 7.01:316

SAŽETAK

Tržišta umetničkih dela nisu homogena, razlika postoji pogotovo između umetničkih proizvoda koji se mogu tehnički reprodukovati i proizvoda-unikata. Kod prvih, regulacije tipa autorskih prava uvode neke specifičnosti (autor zadržava određena prava nad predmetom u cirkulaciji-npr. može da ga ukloni iz opticaja). Kod unikatnih blaga, potražnja se određuje prema ukusu kupaca, dakle ne proizlazi iz nekog opšte važećeg osnova: ta blaga imaju cenu, ali nemaju vrednost. Ali pošto kod reproduktibilnih umetničkih dela njihova estetska priroda podleže istim zakonima kao kod unikatnih dela, ekonomija unikatnih umetničkih dela može nam poslužiti za paradigmu ekonomije umetničkih dela uopšte. Prema teoriji koju je razvio Rade Pantić, cena unikatnih umetničkih dela je monopolska renta. Kao svaka renta, određuje se vanekonomskim mehanizmima. Ti mehanizmi bi trebalo da $\mathrm{u}$ isto vreme dopuštaju slobodu individualnih ukusa i da obezbeđuju jedinstveno polje unutar kojeg ti idiosinkratički stavovi mogu međusobno opštiti. Mehanizmi koji određuju rentu (cenu) umetničkih dela su dakle ideološki aparati, koji sebe i svoje elemente (individualne sudove ukusa) predstavljaju kao neideološke, a sudove još posebno obrazuju u individualne recepcije, otvorene za „interpretacije”, tj. u kognitivno-afektivnu građu za obradu u specifičnim simboličkim formacijama (u kuratorskim praksama, kritici, filozofskoj intervenciji...). Kod savremene umetnosti, struktura ideoloških aparata reprodukuje dominaciju-kroz-fragmentaciju, tipičnu za savremeni kapitalizam.

KLJUČNE REČI

umetničko tržište, estetska ideologija, opšti i posebni

skepticizam, ideološki aparati
PRELIMINARY PAPER

Received: February 18, 2019

Accepted: April 4, 2019

DOI: $10.31664 / z u .2019 .104 .04$

UDC: $7.01: 316$

\section{SUMMARY}

Art markets are not homogeneous, the difference being especially between the art products that can be technically reproduced and the unique products. As for the former, regulations of the copyright type introduce certain specificities (the author retains some rights over the object in circulation-for example, she or he can withdraw it). In case of unique goods, the demand is determined by the buyers' tastes and does not result from some generally valid presupposition: thus, these goods have a price, but they have no value. Since the aesthetic nature of the reproducible works of art is subject to the same laws as the unique artworks, the economy of unique artworks can serve as a paradigm for the economy of artworks in general. According to a theory developed by Rade Pantic, the price of unique artworks is a monopoly rent. As any other rent, it is determined by non-economic mechanisms. These mechanisms should allow for the freedom of individual tastes and at the same time provide a unique field within which these idiosyncratic attitudes can interact. The mechanisms determining the rent (price) of artworks are therefore ideological apparatuses that present themselves and their elements (individual taste judgments) as non-ideological, and moreover formulate the judgments as individual receptions open to “interpretation," i.e. as cognitive-affective material to be processed in specific symbolic formations (in curatorial practices, art criticism, philosophical interventions, and alike). In contemporary art, the structure of ideological apparatuses reproduces domination-through-fragmentation, typical of contemporary capitalism.

\section{KEYWORDS}

art market, aesthetic ideology, general and special scepticism, ideological apparatuses

\section{Rastko Močnik}

Fakultet za medije i komunikacije, Univerzitet Singidunum, Beograd /

Faculty of Media and Communications, Singidunum University, Belgrade 
Ovaj zapis zasniva se na analizi Radeta Pantića ${ }^{1}$ prema kojoj je cena umetničkih dela monopolska renta, a monopolski status umetničkim radovima obezbeđuju ideološki aparati koji su „materijalna egzistencija” ${ }^{2}$ estetskog fetišizma (autonomija umetničke sfere) ${ }^{3}$ i pravnog fetišizma ${ }^{4}$ (autorska prava). U ovom zapisu ćemo predstaviti mehanizme „vanekonomskog" priznanja kojim institucije umetnosti garantuju umetničkim delima ekonomski status i time im omogućuju da se pojave na tržištu umetnosti.

Ideološko posredovanje već je u prošlosti ${ }^{5}$ bilo nužna karika između proizvodnje umetničkih dela i njihove tržišne cirkulacije. U savremenoj situaciji cirkulacija umetničkih dela dodatno se odvojila i od njihove potrošnje. Umetničke kolekcije banaka i korporacija u prvom redu nisu namenjene publici, tj. estetskoj potrošnji, ni samo demonstraciji moći i raskoši, ${ }^{6}$ nego su u prvom redu parkirališta fiktivnog kapitala i osiguranje protiv rizika u budućnosti. Umetnička dela kvalifikuju se za robu, tj. dobijaju ekonomski status kroz estetsko priznanje koje ih izbacuje na tržište, tj. u cirkulaciju-a iz nje, kao robe, kao ekonomski predmeti, ne izlaze nužno u potrošnju, nego se često zadržavaju u nekoj specifičnoj tezauraciji. Dok borave u kolekcijama banaka, korporacija ili privatnika, umetnička dela su privremeno izuzeta iz cirkulacije (i mogu biti povremeno izložena za estetsku konsumpciju šire javnosti), ali zadržavaju i ekonomski i estetski status. Njihova „aprecijacija” zavisi od toga koliko figurišu u transakcijama ustanova umetnosti (da li se o njima piše, da li ih se traži na posudbu za izložbe itd.) - a u suprotnom slučaju, ako ih se zaboravlja, njihova cena opada. Otuda interes tezauratora umetničkih dela (banaka, korporacija, kolekcionara) da kao kulturne mecene podržavaju muzeje i galerije, akademske i naučne ustanove, izdavače, časopise, simpozijume, kritičare, umetnice i umetnike-da, dakle, održavaju art-system. ${ }^{7}$

Ova situacija nastala je ukrštanjem dva izvorno nezavisna istorijska procesa: imanentnog razvoja u umetnosti posle istorijskih avangardi i odaziva kapitala na krizu koja je počela polovinom sedamdesetih godina dvadesetog veka i najavila je „fazu B”, tj. fazu konačnog opadanja „američkog” dugog sistemskog ciklusa akumulacije. ${ }^{8}$

U padajućoj fazi profiti opadaju i smanjuju se prilike za investiranje. „Suvišni” kapital beži na područja sa visokom profitnom stopom i prilikama za investiranje (sada istočna, južna i jugoistočna Azija) ili se ulaže u finansijske spekulacije. Vrednosni papiri koji proizlaze iz finansijalizacije predstavljaju pravo na buduću vrednost-koja će biti ili, možda, neće biti proizvedena. Tražeći načine da izbegne rizike, kapital se može ulagati u kolekcije umetničkih dela za koja se smatra da će održati ili čak povećati svoju cenu. Takva strategija individualnih kapitala stvara kao kolateralnu dobit za celokupni kapital novo područje gde se u oskudici investicionih prilika može ulagati-tržište umetničkih dela.

Drugi proces izazvala je realizacija avangardističkog projekta da se umetnost oslobodi iz estetske kule od slonovače
1 Pantić, „Ka kritici političke ekonomije umetničkog dela”. 2 Tezu „ideologija ima materijalnu egzistenciju" uveo je Louis Althusser u djelu Ideologija i državni ideološki aparati.

Formiranje autonomne kulturno-umetničke sfere počinje u renesansi, a završava tek u 19. veku sa l'art-pour-l'art. Vidi: Breznik, Kultura danajskih darov. 4

Koncept pravnog fetišizma uveo je sovjetski teoretičar prava Jevgenij Pašukanis. Vidi: Pašukanis, Opšta teorija prava i marksizam. Prema Pašukanisu, pravni fetišizam je nužna dopuna robnog fetišizma: kad proizvod postaje roba, njegov vlasnik i njegov kupac postaju pravne osobe. Kad robna proizvodnja zahvati posebno područje umetničke proizvodnje, autor postaje prvim vlasnikom svog proizvoda-robe, tj. umetničkog dela, i kao pravna osoba uživa autorska prava u vezi s njim. 5

U tom se smislu može reći da je postojanje tržišta umetničkih dela uslov za emancipaciju umetničke prakse od zanatske proizvodnje. U zanatskoj je situaciji kupac obično naručio izradu artefakta i u ugovoru sa umetnikom-zanatlijom odredio karakteristike proizvoda: format, siže, boje... i cenu. U zanatskoj situaciji na tržištu nisu dela nego majstorske radionice $\mathrm{i}$ pojedini majstori. Ili „društveno odgovornog preduzetništva”, kao što se sada kaže. 7

U nekim državama dodatni motiv za nabavljanje umetničkih dela su porezne olakšice za ulaganja tog tipa.

Arrighi, The Long Twentieth Century; Wallerstein, Uvod u analizu svjetskog sistema; Volerstin, Opadanje američke moći. 
1 Pantić, "Ka kritici političke ekonomije umetničkog dela." 2 The hypothesis that "ideology has a material existence" was introduced by Louis Althusser in Ideology and Ideological State Apparatuses. 3

The creation of an autonomous sphere of culture and art started in the Renaissance and was completed only in the Igth century, with the l'art-pour-l'art movement. Cf. Breznik, Kultura danajskih darov.

4

The concept of legal fetishism was introduced by the Soviet theoretician of law, Evgeny Pashukanis. Cf. Pashukanis, The General Theory of Law and Marxism. According to Pashukanis, legal fetishism is a necessary addition to commodity fetishism: when a product becomes a commodity, its owner and buyer become legal persons. When commodity production captures the specific area of artistic production, the author becomes the first owner of his product-commodity, which is the artwork, and as a legal person enjoys copyright in relation to it. 5

In this sense, one may say that the existence of an art market is a condition for the emancipation of artistic practice from craft production. In the situation of craft production, the customer usually orders an artefact and defines the features of the product in advance, in a contract with the artisan: its format, size, colour... and price. In this situation, it is not the artefacts that are on the market, but individual masters or master workshops.

Or "socially responsible entrepreneurship," as one calls it nowadays.

7

In some countries, an additional motive for purchasing artworks may be the tax reliefs granted for investments of this type.

8

Arrighi, The Long Twentieth Century; Wallerstein, World-Systems Analysis; Wallerstein, The Decline of American Power.
This paper is based on Rade Pantić's thesis that the price of artworks is monopoly rent. ${ }^{1}$ The monopoly status of artworks is provided by the ideological apparatuses that are the "material existence" 2 of aesthetic fetishism (autonomy of the art sphere $)^{3}$ and legal fetishism ${ }^{4}$ (copyright). In this analysis, we will present the mechanisms of "non-economic" recognition by which art institutions guarantee the economic status to artworks, thus enabling them to enter the art market.

Throughout history, ${ }^{5}$ ideological mediation has been a necessary link between the production of artworks and their market circulation. In the modern situation, the circulation of artworks has further detached itself from their consumption. The artistic collections of banks and corporations are not primarily intended for the public, i.e. for aesthetic consumption, and are not even primarily meant as a demonstration of power and luxury; ${ }^{6}$ they primarily serve as deposits of fictitious capital and insurance against future risks. Artworks qualify for commodities, i.e. they gain the economic status through the aesthetic recognition that launches them upon the market, i.e. into circulation - and thence, as commodities, as economic objects, they do not necessarily proceed into consumption, but are often retained in some specific sort of thesauration. While staying in the collections of banks, corporations, or private individuals, these artworks are temporarily exempted from circulation (and may only be occasionally exposed to the general public for aesthetic consumption), but they retain their economic and aesthetic status. Their "appreciation" depends on how much they figure in the transactions of art institutions (whether they are written about, demanded on loan for exhibitions, etc.) - for if they fall into oblivion, their price will fall. Hence the thesaurators of artworks (banks, corporations, collectors) have the interest to support, as cultural sponsors, museums and galleries, academic and scholarly institutions, publishers, magazines, symposia, art critics - that is, they have an interest to reproduce the art system. ${ }^{7}$

This situation has resulted from the conjuncture of two originally independent historical processes: the immanent development in art after the historical avant-gardes, and the response of capital to the crisis that began in the midI970s and heralded the "phase B," i.e. the final decline of the "American" systemic cycle of accumulation. ${ }^{8}$

In this declining phase, profits are decreasing and investment opportunities are reduced. The "surplus" capital flows to the areas with high profit rates and investment opportunities (now the East, South, and South-East Asia) or is invested into financial speculation. Securities resulting from financialization represent the right to future value -which may, but need not be produced. Seeking for the ways to avoid risks, capital may be invested in collections of artworks that are believed to maintain or even increase their price in the future. This strategy of individual capitals creates the art market as a collateral gain, a new area for the total capital, where one can invest during the shortage of investment opportunities. 
i interveniše u realnu istoriju. ${ }^{9}$ Tu realizaciju omogućio je susret umetničkih avangardi sa socijalističkom revolucijom, čime se otvorio burni period „post-estetskih” pokreta i praksi (proletkult, produktivizam itd.). ${ }^{10}$ Te inicijative ubrzo su bile potisnute post-avangardističkim modernizmom i, u jednom kraćem periodu, socijalističkim realizmom. ${ }^{11}$ Postavangardna modernistička linija završila se konceptualizmom kada je postalo očito da umetnost ne poseduje više svoju vlastitu tehničku problematiku. Pošto je tehnika do tada bila način na koji je umetnička praksa rešavala svoja protivrečja, time se otvorila nova istorijska epoha: epoha savremene umetnosti u kojoj umetnička praksa nije više sama sebi dovoljna. Sa jedne strane treba joj dopuna u priznanju institucija „sveta umetnosti" ${ }^{12}$ - a sa druge strane svoj siže pozajmljuje kao „ready made” od drugih ideologija ili iz svakodnevnog zdravorazumskog rezoniranja, tj. iz vladajuće ideologije.

Savremeni artefakt svoju umetničku pretenziju zasniva na estetskoj ideologiji nezavisnosti od društveno-istorijskih uslova svoje proizvodnje, a za realizaciju te pretenzije zavisan je od sebi spoljašnjih ideoloških transakcija. Ali ako je pojedinačni artefakt heteronoman, njegova promocija u umetničko delo zavisi od autonomije estetskih ideoloških aparata, dakle od specifično buržoaskog formiranja društva u nezavisne sfere ekonomije, pravno-političke i ideološke nadgradnje. ${ }^{13}$

Ideološki mehanizmi koji podupiru i reprodukuju autonomnu estetsku sferu imaju strukturu posebnog skepticizma koju su antropolozi izučavali u magijskim praksama: društva koja praktikuju magiju kritički prosuđuju postupke svakog pojedinačnog šamana, ali veruju u magiju uopšte. Posebni skepticizam je skepticizam u svakom pojedinačnom slučaju, a njegov je osnov opšte verovanje koje pruža merilo za kritičko prosuđivanje pojedinih magijskih radnji. Takva je i struktura estetskog prosuđivanja: kritički odnos prema svakom pojedinačnom artefaktu zasniva se na opštem verovanju u umetnost koje nudi implicitnu normu šta je „dobro” ili „uspelo” umetničko delo. ${ }^{14}$ Pokazaćemo da je mehanizam posebnog skepticizma u savremenoj umetnosti ipak drugačiji nego u magiji.

U eseju „Vrač i njegova magija” ${ }^{15}$ Lévi-Strauss komentariše Boas-ov zapis autobiografije kvakiutlskog šamana Quesalid-a koji je smatrao da su šamani većinom varalice, ali je tvrdio da je jedanput sreo jednog koji je bio „pravi”. Struktura je: skepticizam prema pojedinim praktikantima i verovanje da je prava magija ipak moguća. U članku „Simbolička delotvornost” ${ }^{16}$ Lévi-Strauss objašnjava efikasnost magijskog lečenja bolova kod teškog porođaja time da šamanove inkantacije simbolizuju fiziološke procese koji, nesimbolizovani, prouzrokuju bol. Prema LéviStrauss-u, mitološki „prevod” bolova u šamanovom bajanju služi kao označitelj čiji su označenik bolni fiziološki procesi. Međutim, semiotika magijskog delovanja je komplikovanija: bolovi su naime već „označitelj” ili „izraz” fizioloških procesa.
9

Za kratak opis procesa od avangardi do savremene umetnosti, vidi: Močnik, „U umetnosti, savremenost počinje 1917”. 10 Ili, u Jugoslaviji, stvaralaštvo narodnooslobodilačkog pokreta i socijalističke revolucije. Vidi: Miletić, Radovanović, Lekcije o odbrani; Kirn, Habjan, „The Yugoslav Partisan Art”. 11

Statut Saveza pisaca SSSR, donet na prvom kongresu sovjetskih pisaca godine 1934., odredio je socijalistički realizam kao osnovni metod sovjetske literature i kritike. U Sovjetskom savezu artističke prakse počele su napuštati socijalistički realizam tokom šezdesetih godina. U Jugoslaviji su praktikovali socijalistički realizam posle 1945. Decembra 1949. Edvard Kardelj je u predavanju na Slovenskoj akademiji nauka i umetnosti osudio ždanovizam. („Ždanovizam” je praksa partijskog propisivanja „podobnih” pravaca u kulturi i umetnosti. Naziva se prema Andreju Aleksandroviču Ždanovu, starom boljševiku i visokom državno-partijskom funkcioneru, koji je između godina 1945. i 1948. rukovodio sovjetskom kulturnom politikom.) Treći plenum CK KPJ decembra 1949. uveo je novu politiku jugoslovenskih komunista na područjima školstva, kulture i ideologije. Na drugom savetovanju mladih književnika u Ljubljani godine 1950. odbacili su načelo socijalističkog realizma. Referat Miroslava Krleže na 3. kongresu književnika Jugoslavije godine 1952. u Ljubljani važi kao konačni raskid sa socijalističkim realizmom u Jugoslaviji. (Vidi: Pantić, „Elitno i popularno u jugoslovenskoj filmskoj kulturi 1945-1965”, 111.) - „Front socijalističkog realizma je za kratko trijumfovao nakon Drugog svetskog rata i revolucije, ali nakon raskida sa Staljinom bio je iskritikovan i zamenjen upravo kontradiktornom Krležinom formulacijom jedinstva autonomije umetnosti i političkog anagažovanja. Krležin govor na Trećem kongresu Saveza književnika Jugoslavije u Ljubljani 1952. godine obično se tumači kao prekretnica u kulturnoj politici Jugoslavije i signal definitivnog raskida sa socijalističkim realizmom, kao i uvođenja autonomizacije umetnosti od politike.” Pantić, „Od kulture u ,socijalizmu' do socijalističke kulture”, 193. 12

Termin je uveo Arthur Danto u filozofskom eseju „The Artworld”. 13

O počecima formiranja moderne autonomne sfere kulture kao kolateralnog produkta finansijskog kapitala u renesansi, vidi: Breznik, Kultura danajskih darov.

14

Koncept „posebnog skepticizma” uveo je Edward E. Evans-

Pritchard u: Witchcraft, Oracles, and Magic among the Azande. Taj konceptualni aparat dalje je razvio Geoffrey E. R. Lloyd u: Magic, Reason and Experience. Maja Breznik konceptualizirala je tu problematiku u proučavanju umetničkih praksi u: „General skepticism in the arts”. 15

Lévi-Strauss, „Vrač i njegova magija”. 16

Lévi-Strauss, „Simbolička delotvornost”. 
For a short overview of the process, from avant-garde to contemporary art, see: Močnik, "U umetnosti, savremenost počinje i9ı7."

10

Or, in Yugoslavia, the art of the National Liberation Movement and the socialist revolution. See: Miletić, Radovanović, Lekcije o odbrani; Kirn, Habjan, "The Yugoslav Partisan Art." 11

The Statute of the Soviet Writers' Union, adopted at the first Congress of Soviet Writers in 1934, defined Socialist Realism as the basic method of Soviet literature and criticism. In the Soviet Union, art practices started to abandon Socialist Realism during the 196os. In Yugoslavia, Socialist Realism was inaugurated after 1945. In December 1949, Edvard Kardelj condemned "Zhdanovism" in a lecture held at the Slovenian Academy of Sciences and Arts. ("Zhdanovism" was the practice of "suitable" orientations in art and culture ratified by the Communist Party, named after Andrey Alexandrovich Zhdanov, an old Bolshevik and high state-party official who ran the Soviet cultural policy between I945 and I948.) The Third plenum of the Central Committee of the Communist Party of Yugoslavia (CK KPJ) in December 1949 introduced a new policy of Yugoslav communists in the fields of education, culture, and ideology. At the Second Convention of Young Writers in Ljubljana in I950, the principle of Socialist Realism was rejected. Miroslav Krleža's speech at the Third Congress of Yugoslav Writers, held in 1952 in Ljubljana, is considered as the final break with Socialist Realism in Yugoslavia. (Cf. Pantić, "Elitno i popularno u jugoslovenskoj filmskoj kulturi 1945-1965.") - “The front of Social Realism briefly triumphed after World War II and the revolution, but after the break with Stalin it was scorned and replaced by Krleža's fully opposing formulation of the unity between artistic autonomy and political engagement. His speech at the Third Congress of the Yugoslav Writers' Association in Ljubljana in $195^{2}$ is usually interpreted as the turning point in Yugoslav cultural policy, heralding a definite break with Socialist Realism and the autonomization of art with regard to politics." Pantić, "Od kulture u 'socijalizmu' do socijalističke kulture," 193.

12

The term was coined by Arthur Danto in his philosophical essay "The Artworld,"

13

On the beginnings of the formation of the modern autonomous sphere of culture as a collateral product of financial capital in the Renaissance, see: Breznik, Kultura danajskih darov.

14

The notion of "specific scepticism" was introduced by Edward

E. Evans-Pritchard in Witchcraft, Oracles, and Magic among the Azande.

The concept was further elaborated by Geoffrey E. R. Lloyd in Magic,

Reason and Experience. Maja Breznik has integrated into this problem field the study of art practices. See her article "General Skepticism in the Arts."

15

Lévi-Strauss, "The Sorcerer and His Magic." 16

Lévi-Strauss, "The Effectiveness of Symbols."
The second process is a consequence of the avant-garde project of liberating art from the ivory tower of aestheticism and making it intervene into real history. ${ }^{9}$ The realization of this project was made possible when artistic avant-gardes encountered socialist revolutionary movement. This led to a turbulent period of "post-aesthetic" movements and practices (Proletkult, Productivism, and so on). ${ }^{10}$ These initiatives were soon suppressed by post-avantgarde modernism and, for a briefer period, by Socialist Realism. ${ }^{11}$ The post-avantgarde modernist line ended in Conceptualism, when it became evident that art no longer possessed its own technical problem field. Since technique had been the way in which artistic practice resolved its contradictions, the "loss" of specific artistic techniques ushered a new historical epoch: the epoch of contemporary art, in which art practice is no longer self-sufficient. On the one hand, it now has to be complemented by the recognition of "artworld" ${ }^{12}$ institutions, while on the other it is borrowing its elements as "ready made" from other ideologies or from everyday, common-sense reasoning, i.e. from the ruling ideology.

The contemporary artefact bases its artistic claim on the aesthetic ideology of its independence from the socio-historical conditions of its production. For the realization of this claim, it depends on external ideological transactions. While the individual artefact is heteronomous, its promotion into an artwork depends on the autonomy of aesthetic ideological apparatuses, hence on the specific bourgeois social formation, composed of the relatively autonomous economic sphere, the relatively autonomous juridical-political sphere, and the relatively autonomous ideological sphere. ${ }^{13}$

\section{Ideological mechanisms that support and reproduce the} autonomous aesthetic sphere have the structure of specific scepticism that the anthropologists have researched in magical practices: the societies practicing magic critically judge the actions of each individual shaman, yet they believe in magic in general. Specific scepticism implies being sceptical in specific cases, while its foundation is a general belief that provides the criterion for critically assessing the individual performances. The structure of aesthetic judgment looks much the same: critical attitude towards each individual artefact is based on a general belief in art, which offers an implicit norm for judging a "good" or "successful" artwork. ${ }^{14}$ We will show that the mechanism of specific scepticism in contemporary art is nevertheless different from that in magic.

In his essay "The Sorcerer and His Magic," ${ }^{15}$ Lévi-Strauss commented on Boas' record of the autobiography of Kwakiutl shaman Quesalid, who thought that the shamans were mostly frauds, but claimed that once he had met a "true" one. The structure was thus to be sceptical towards individual practitioners, yet to believe that true magic was possible. In his essay "The Effectiveness of Symbols," ${ }^{16}$ Levi-Strauss explained the effectiveness of magical pain management in difficult births, where shamanic incantations symbolized the physiological processes that, non-symbolized, have been causing pain. 
Lévi-Strauss-ovu teoriju treba dakle formalizovati kompleksnijom semiotičkom šemom nego što je Saussure-ov par „označitelj/označenik”. Pomoći će nam Hjelmslevljev prošireni model koji uz par „izraz/sadržaj”, analogan Saussureovom, dodaje i razlikovanje „forma/supstanca”. ${ }^{17}$ Ako LéviStrauss-ovu analizu formaliziramo prema toj šemi, bolovi su supstanca izraza, a fiziološki procesi supstanca sadržaja; forma nedostaje i kod izraza i kod sadržaja-dakle, ni jedan ni drugi nisu simbolizovani. Šamanovo uobličenje bolova u mitološke predstave dodaje izrazu njegovu formu i time omogućava psihološko savladavanje bolova, ako ne čak i fizioloških procesa koji ih prouzrokuju.

Pošto konceptualiziramo magijsku, a ne jezičku praksu, treba da odredimo koji elementi društvene semiotike, koja podržava magijsku delotvornost, povezuju konceptualne parove telesne semiotike. Šamanova ritualna radnja je diskurzivna praksa koja aktuelizuje kolektivnu pozadinu verovanja. Izrazi koji figurišu u inkantaciji pripadaju zajedničkom ideološkom rečniku, njihovo povezivanje određuje kolektivni ideološki program. ${ }^{18}$ Tom programu pripada i veza koja povezuje mitološku naraciju telesnom boli: tačnije, u kolektivnom ideološkom programu šamanovo bajanje već figuriše kao forma izraza kojeg supstanca je telesna bol. Individualna šamanova ritualna radnja povezuje izraz (inkantacija, gestovi, manipulacija) sa sadržajem (mitološke predstave), a kolektivni ideološki program iz jedinstva „inkantacija + mit" pravi formu izraza koji za svoju supstancu ima telesnu bol.

Telesna semiotika konstituiše se zapravo tek kroz magijsku intervenciju: bez nje, tu je samo bespomoćno neartikulisano pateće telo. Kao „dodatak”, suplement šamanova magijska radnja retroaktivno uspostavlja telesnu semiotiku, dodajući joj dimenziju forme, tj. simbolizujući je. Pre magijske intervencije, telesna bol je deo fizioloških procesa. Ali magijsko oformljenje pretvara je u psihološki izraz fiziološkog sadržaja i time je čini dostupnom individualnim psihološkim radnjama pateće individue. U telesnoj semiotici individualni psihološki automatizam koji nosi (ili iziskuje) ${ }^{19}$ kolektivno verovanje povezuje supstancu (sadržaj: fiziološki procesi; izraz: telesna bol) i formu (magijska radnja svojim izrazom - šamanovim operacijama; i sadržajem-mitološkim predstavama). A supstancu sadržaja (fiziološke procese) sa supstancom izraza (bol) povezuje individualna psihološka radnja koja minimalno ovladava bol, a maksimalno i fiziološke procese.

\section{Magijski mehanizam možemo predstaviti Šemom 1.}

Istim konceptualnim aparatom možemo predstaviti mehanizme posebnog skepticizma u savremenoj estetskoj ideologiji. Ni tu se semiotika umetničkog dela ne konstituiše sve dok nije dopunjena estetskom validacijom ideoloških aparata kulturne sfere. Prakse u kulturno-umetničkim ideološkim aparatima su heterogene, heterogeni su i njihovi produkti. Heterogenost ne proizlazi samo iz razlika u specifičnim istorijskim počecima i kasnijim reartikulacijama pojedinih aparata, ${ }^{20}$ nego je imanentna savremenoj estetskoj ideologiji koja

\section{7}

Jezički znak „drvo”, na primer, se prema Hjelmslevu opisuje ovako: IZRAZ (odgovara Saussure-ovom označitelju): supstanca izraza: zvučna masa kod izgovora te reči ili grafizam kod njenog zapisa; forma izraza: pravilan niz fonema srpskog jezika (fonema se definiše kao snop distinktivnih obeležja koja određuju njene odnose prema ostalim fonemama jezika); SADRŽAJ (odgovara Saussure-ovom označeniku): supstanca sadržaja: ideja, predstava ili „koncept” drveta; forma sadržaja: strukturni semantički opis (tipa: + fizički predmet,+živo biće,+ biljka...). A u Mefistofelovoj replici u Goethe-ovu Faustu: „Grau, teurer Freund, ist alle Theorie und grün des Lebens goldner Baum.Siva, prijatelju dragi, teorija je sva, a zeleno života zlatno drvo." -izraz „Baum, drvo” mogao bi se opisati ovako: supstanca izraza: zvučna masa kod izgovora te reči ili grafizam kod njenog zapisa-a pošto se radi o stihu, u supstancu izraza ulazi i zvučna vrednost reči, pogotovo zvučni kontrast „Theorie/Baum” (uski vokali, rogobatna grupa e-o/široki vokal $a$, blago zvučna grupa $a-u$ ); forma izraza: pravilan niz fonema nemačkog jezika - a pošto se radi o stihu, u formu izraza ulazi i metrička šema reči; supstanca sadržaja: ideja, predstava drveta-a pošto se radi o metafori, iznad predstave drveta uzdiže se raskošna predstava životne snage, rasti prema nebu itd.; forma sadržaja: na strukturni semantički opis nakalemljuju se potezi tipa + vitalizam, + autentičnost, + neposrednost, + iskrenost, + velikodušnost itd. - Hjelmslev, Prolegomena to a Theory of Language. Vidi takoder: Bart, Elementi semiologije.

18

Isto važi za ritualne gestove i predmete kojima ritual eventualno manipuliše-ali te elemente Lévi-Strauss ne pominje.

19

Prema Durkheim-ovom diktumu: „Jer, u isto vrijeme dok nam se institucije nameću, mi držimo do njih, one nas prisiljavaju, a mi in volimo; one nas prinuđuju, a mi nalazimo svoju korist u njihovu djelovanju čak i u toj prinudi." Durkheim, Pravila sociološke metode, 16 (napomena 4). 20

Univerzitet je srednjovekovna cehovska ustanova, kasnije reartikulisana u nacionalnu ustanovu i sada u dobavljača kvalifikovanih radnica i radnika na tržište radne snage; galerija je kasna renesansna ustanova, kasnije reartikulisana u komercijalnog posrednika; umetničke akademije su monarhijska ustanova, reartikulisana kasnije u nacionalnu ustanovu, a sada u institucije globalnog art-sistema itd. Za istorijsku analizu klasične monarhijske akademije, vidi: Pezelj, Umetnost in disciplina. 


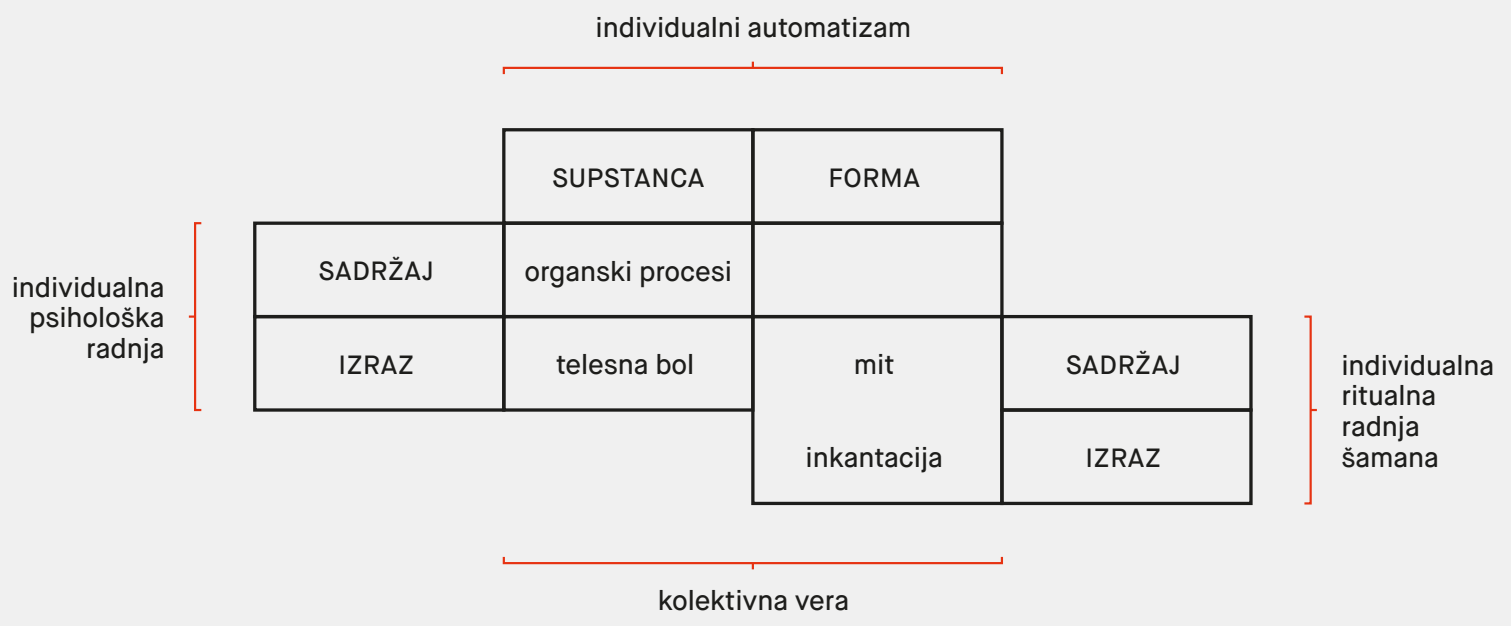


već od proglašenja bezinteresnosti estetskih praksi, njihovih proizvoda i njihove percepcije zahteva ireduktibilno individualnost i dakle „pluralnost” estetskih sudova. Upravo ta liberalna estetska ideologija objedinjuje inače heterogene aparate $u$ autonomnu umetničko-kulturnu sferu. ${ }^{21}$ Bez obzira na svoju eventualnu ideološku tendenciju, artefakt sa umetničkom pretenzijom postaje umetničkim delom posredstvom vladajuće liberalne estetske ideologije, konstitutivne za buržoasku kulturno-umetničku sferu.

Različite pisane i usmene prezentacije artefakta, kritike, teorije, književna dela koji referišu na nj, eseji, polemike, izložbe, katalozi itd., sav paper trail ${ }^{22}$ koji artefakt ostavlja u javnosti su onda izrazi, nosioci sadržaja (interpretacija, opisa, konceptualizacija, ideoloških eksploatacija itd.) semiotičke suplementacije koja kao forma izraza simbolizuje artefakt i pretvara ga u umetničko delo. Na nivou sveta umetnosti izraze povezuju sa njihovim sadržajima prakse (individualnih i institucionalnih) agenata umetničkog sistema koje skladno sa tržišnom tendencijom ka veštačkoj diferencijaciji proizvoda teže da budu posredovane različitim ideologijama, ali su objedinjene vladajućom liberalnom ideologijom estetske autonomije. Ovaj semiotički (i „semiotizujući”) dodatak-dopunu povezuju sa (suplementacijom stvorenom) semiotikom umetničkog dela aparati estetske ideologije ili „svet umetnosti”, kako ih je romantički nazvao Arthur Danto. ${ }^{23} \mathrm{U}$ semiotici umetničkog dela celina dopunskog elementa (izraz + sadržaj) figuriše kao forma izraza. Dopunski element obrazuje supstancu izraza (=artefakt) u element umetničke semiotike koji izražava sadržaj sa „reprezentativnom” ${ }^{24}$ supstancom i formom koju određuje konstelacija „umetnički relevantnih predikata”. Dopunski element dalje sugeriše adekvatnu individualnu recepciju umetničkog dela, omogućujući joj da poveže sadržaj sa formom. A sadržaj je sa izrazom uvek već povezivala estetska ideologija posebnog skepticizma kod kultivisanih posmatrača i posmatračica.

Semiotiku savremenog funkcionisanja umetničkog dela možemo predstaviti Šemom 2.

U semiotičkoj šemi estetske ideologije pojavljuje se izrazita polarizacija „aparati/individue” koje kod magije nema. U magiji, individualni šaman je jedan od više aparata dominantne ideologije, dok su individualne psihološke radnje njegove „pacijentkinje” učinci integracije rodilje u tu ideologiju i njene aparate. Terapeutsku efikasnost individualne psihologije izazivaju tek šamanove radnje. Našu šematizaciju Lévi-Strauss-ove teorije magije treba dakle posmatrati i kao šematizaciju specifičnog-magijskog tipa ideološke interpelacije.

Šema estetske ideologije prikazuje estetsku ideološku interpelaciju. Pored polarizacije „aparati/individue”, njena specifičnost je i buržoaski ideološki pluralizam u oba pola i objedinjujuće delo vladajuće (estetske) ideologije. Suprotni polovi distribuisani su inverzno simetrički: dok su prakse agenata umetničkog sistema konjunkturna, dinamička dimenzija aparata, umetničke institucije njihova su strukturna, statička

\section{1}

Autonomija umetničko-kulturne sfere i njena objedinjujuća liberalna ideologija zadržavaju imanentnu konfliktnost umetničkih praksi i aparata u okvirima buržoaskog pluralizma i sprečavaju da unutrašnja umetnička i kulturno-ideološka protivrečja postaju antagonistička. Jedno istraživanje umetničkih ideologija umetnica i umetnika u Sloveniji pokazalo je da se na posebnim umetničkim područjima razvijaju specifični konflikti kroz koje se prelamaju konstitutivne odrednice sukobljenih praksi: na području performativnih umetnosti savremene (,alternativne”) prakse i institucije sukobljavaju se sa ustanovama nacionalne pozorišne umetnosti; na muzičkom području alternativne i inovativne prakse (i njihovi inače marginalni „aparati”) sukobljavaju se sa agencijama za skupljanje i redistribuciju dohodaka od autorskih prava zbog njihovog protežiranja komercijalnih autora i izvođača; u izdavaštvu mali nekomercijalni izdavači u konfliktu su sa velikim komercijalnim; samo na području vizuelnih umetnosti vlada opšte pomirenje, osigurano poklapanjem estetskog i robnog fetišizma (umetnice i umetnici smatraju da cena umetničkog dela izražava njegovu estetsku vrednost i da je za svakog stvaraoca nužno da se plasira u međunarodni art-sistem). Vidi: Breznik, Posebni skepticizem $\checkmark$ umetnosti.

22

Paper trail: „a series of documents that show a record of your activities” (Cambridge Advanced Learner's Dictionary); „documents (such as financial records) from which a person's actions may be traced or opinions learned” (Merriam-Webster); „written evidence or records of someone's activities" (Collins). 23

Danto, „The Artworld”. Danto-ova filozofija umetnosti pogodna je za naše svrhe, jer sistematizuje savremenu estetsku ideologiju i pogotovo njenu sposobnost da integriše navodno „subverzivne” artefakte koji su u savremenoj umetnosti takoreći standard. Prema Danto-u, ono što od artefakta pravi umetničko delo je njegov specifični „umetnički relevantan predikat”. Kao što smo drugde pokazali, novi (i eventualno subverzivni) umetnički relevantni predikat retroativno reartikuliše sistem prethodnih predikata i time otvara mogućnost njihovih novih kombinacija. Duchamp-ova Fontana, na primer, prema Danto-u uvodi nov umetnički relevantan predikat „ready made” i time dodaje prošlim delima predikat „nije ready made”. Za reformulaciju Danto-ove filozofije u teoriju, vidi: Močnik, „U umetnosti, savremenost počinje 1917".

24

"Reprezentativno” je ovde mišljeno u najširem „durkheim-ovskom” značenju, tako da obuhvata i „nereprezentativne” simboličke formacije (apstrakciju i tome slično). 


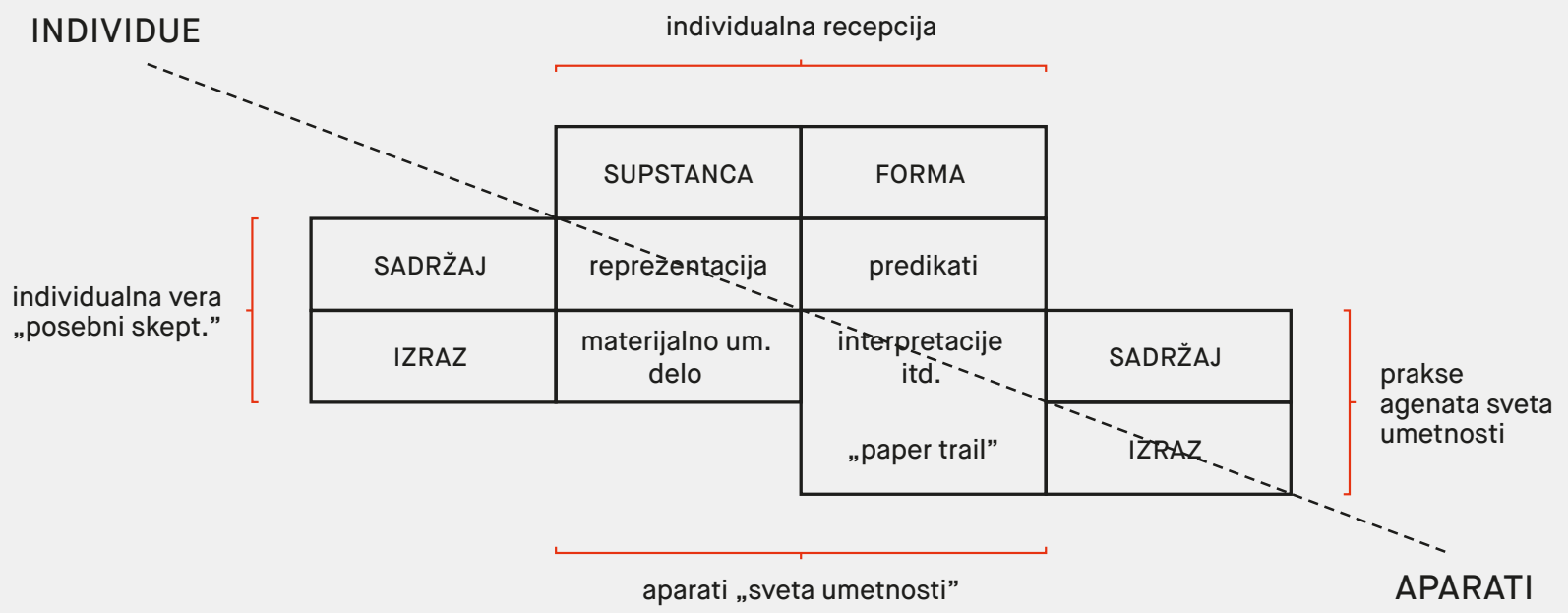




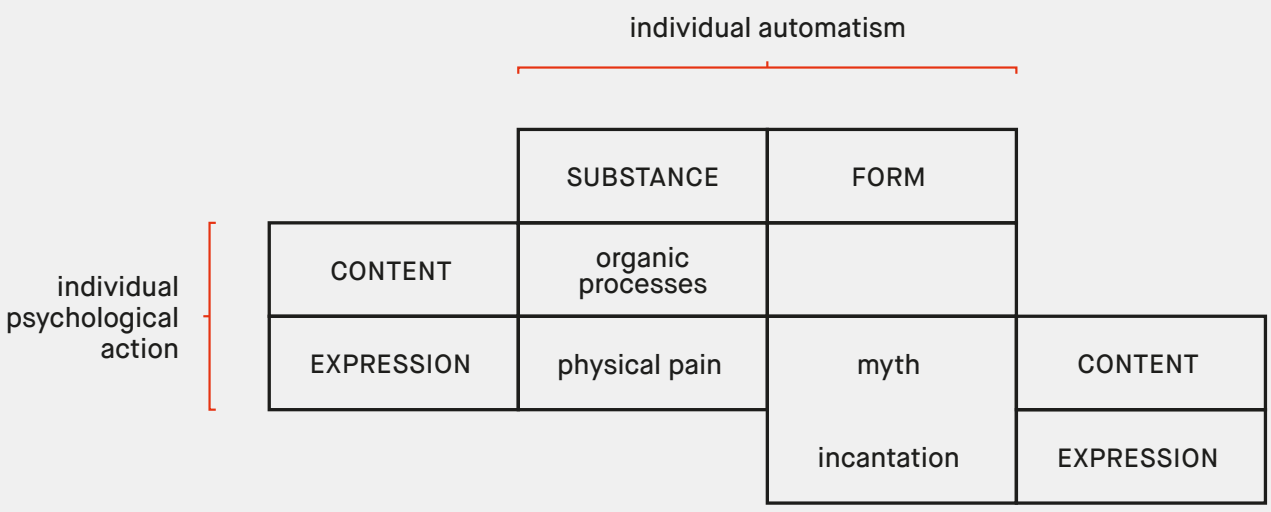

shaman's

individual

ritual action

collective belief 
17

The linguistic sign "tree," for example, is described by Hjelmslev as follows: EXPRESSION (corresponds to Saussure's signifier) has two dimensions: substance of the expression: the sound mass while pronouncing the word or graphism in writing; form of the expression: the correct sequence of phonemes in the given language (phoneme being defined as a cluster of distinctive features that determine its relations to other phonemes in the language). CONTENT (corresponds to Saussure's signified) has two dimensions: substance of the content: the idea, image, or "concept" of the tree; form of the content: structural semantic description (of the type: + physical object, + living being, + plant...). Thus, in Mephistopheles' line in Goethe's Faust: “Grau, teurer Freund, is alle Theorie and grün des Lebens goldner Baum - All theory, dear friend, is grey, but the golden tree of life springs ever green"-the expression "Baum, tree" may be described as follows: substance of the expression: the sound mass while pronouncing the word or graphism in its writing and since it is a verse, the substance also includes the sound value of words, especially the sound contrast "Theorie / Baum" (narrow vowels, coarse group $e$-o / broad vowel $a$, mildly sounding group $a-u$ ); form of dthe expression: the regular sequence of phonemes in the German language - and since it is a verse, the form also includes the metric scheme of words; substance of the content: the idea or image of the treeand since it is a metaphor, the image of the tree is superseded by a lavish representation of life force, growth towards the sky, etc.; form of the content: structural semantic description is superseded by movements such as: + vitalism, + authenticity, + immediacy, + honesty, + generosity, etc.-Hjelmslev, Prolegomena to a Theory of Language. Cf. Barthes, Elements of Semiology.

18

The same is true about ritual gestures and objects that the ritual might use-but Lévi-Strauss does not mention these elements. 19

According to Durkheim: "For, while institutions bear down upon us, we nevertheless cling to them; they impose obligations upon us, and yet we love them; they place constraints upon us, and yet we find satisfaction in the way they function, and in that very constraint." Durkheim, The Rules of Sociological Method, I6 (note 4).
According to Lévi-Strauss, the mythological "translation" of pain in shamanic incantation serves as the signifier whose signified are painful physiological processes. However, the semiotic of magical action is more complicated: for the pain is itself a "signifier" or "expression” of physiological processes.

Thus, Lévi-Strauss' theory should be formalized as a more complex semiotic scheme than provided by Saussure's "signifier/signified” pair. Hjelmslev's extended model, which along with the "expression/content" pair, analogous to Saussure's, introduces the distinction between "form/substance," may be of help here. ${ }^{17}$ If Lévi-Strauss' analysis is formalized according to this scheme, pain is the substance of the expression, and physiological processes are the substance of the content; the form is missing both in the expression and in the contentwhich means that neither of them are symbolized. Shaman's transformation of pain into mythological images adds form to the expression, making it possible mentally to control the pain, perhaps even to control the physiological processes causing it.

Since we conceptualize magical and not linguistic practice, we need to determine which elements of the social semiotics that supports the efficiency of magic, link together the conceptual pairs of bodily semiotics. Shaman's ritual action is a discursive practice that actualizes the collective religious background. The expressions that figure in the incantation belong to a common ideological vocabulary, and their associations are determined by the collective ideological programme. ${ }^{18}$ This programme includes the link between mythological narration and physical pain: more precisely, in the collective ideological programme, shaman's incantation already figures as the form of expression whose substance is physical pain. His individual ritual action links the expression (incantation, gestures, manipulation) to the content (mythological images), while the collective ideological programme uses the unity of "incantation + myth" to create the form for the expression that has physical pain as its substance.

Bodily semiotics is actually constituted only through magical intervention: without it, there is only a helplessly unarticulated, suffering body. As a "supplement," the shaman's magical action retroactively establishes bodily semiotics, adding the dimension of the form, i.e. symbolizing it. Before the magical intervention, physical pain is part of physiological processes. However, magical formulation turns it into a mental expression of the physiological content, making it available to the individual mental actions of the suffering individual. In bodily semiotics, the individual psychological automatism carried (or required) ${ }^{19}$ by collective belief links substance (content: physiological processes; expression: physical pain) and form (magic action with its expressionshamanic operations; and its content-mythological images). The substance of the content (physiological processes) is linked with the substance of the expression (pain) by the individual mental action that controls at least pain, and perhaps also physiological processes.

The mechanism of magic can be represented as in Scheme I. 


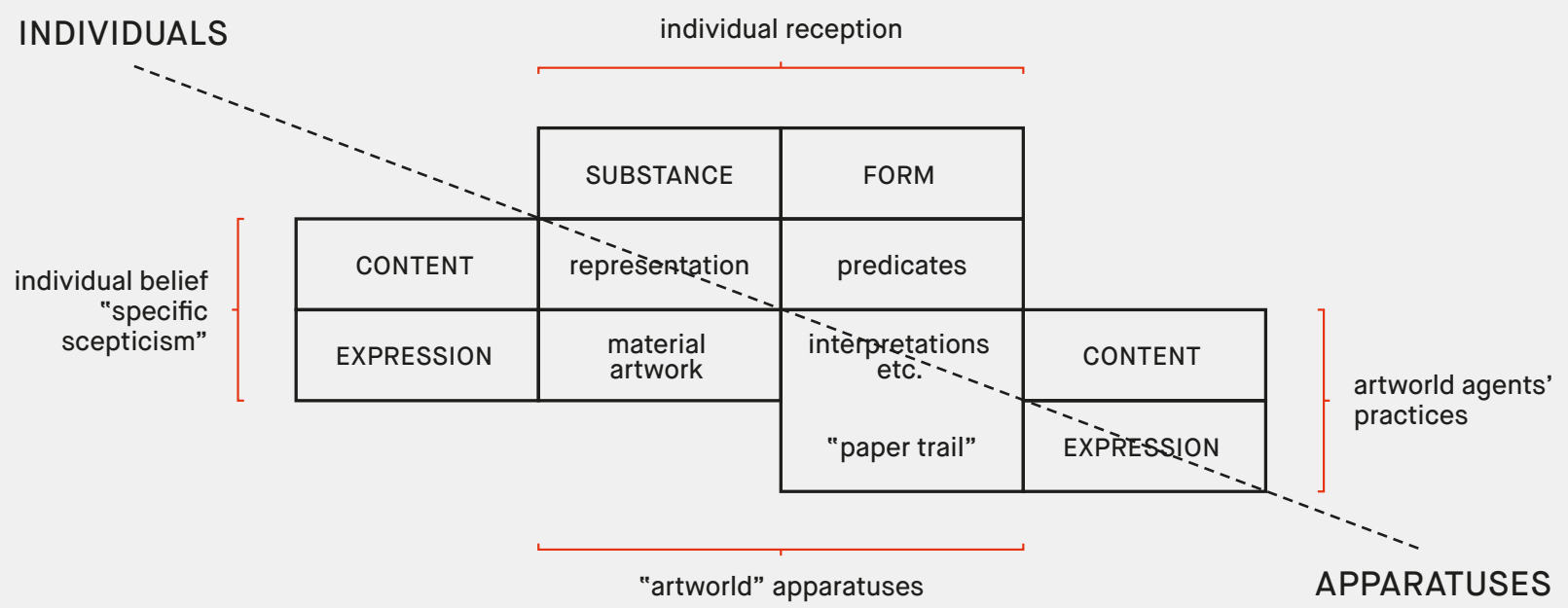


20

The university is a medieval guild institution, later rearticulated into a national institution and then into a supplier of skilled workers for the labour market. The gallery is a late Renaissance institution, later rearticulated into a commercial mediator. The art academy is a monarchical institution, later rearticulated into a national institution, and then into an institution of the global art system; etc. For a historical analysis of the classical monarchical academy, see: Pezelj, Umetnost in disciplina.

21

The autonomy of the artistic-cultural sphere and its unifying liberal ideology retain the immanent conflict of art practices and apparatuses within the framework of bourgeois pluralism, preventing the internal artistic and cultural-ideological contradictions from becoming antagonistic. A study of the artistic ideologies of Slovenian artists has shown that specific conflicts develop in specific artistic areas where the constitutive determinants of the conflicting practices are refracted. In the field of performing arts, the contemporary ("alternative") practices and institutions clash against the institutions of national theatre art. In the field of music alternative and innovative practices (and their otherwise marginal "apparatuses") clash against the agencies for collecting and redistributing copyright income because of their preference for commercial authors and performers. In publishing, small, non-commercial publishers are in conflict with the large, commercial ones. Only in the field of visual arts, there is overall peace, ensured by the coincidence of aesthetic and commodity fetishism (the artists believe that the price of an artwork expresses its aesthetic value and that it is necessary for every artist to be positioned within the international art system). Cf. Maja Breznik, Posebni skepticizem v umetnosti.

22

Paper trail: "a series of documents that show a record of your activities" (Cambridge Advanced Learner's Dictionary); "documents (such as financial records) from which a person's actions may be traced or opinions learned" (Merriam-Webster); "documents which provide evidence of someone's activities” (Collins).

23

Danto, "The Artworld."-Danto's philosophy of art is suitable for our purposes, because it systematizes the contemporary aesthetic ideology and, in particular, its ability to integrate the allegedly "subversive" artefacts, which are practically standard in contemporary art. According to Danto, what turns an artefact into an artwork is its specific "artistically relevant predicate." As we have shown elsewhere, the new (and possibly subversive) artistically relevant predicate retroactively rearticulates the system of previous predicates, thus opening the possibility of their new combinations. Duchamp's Fountain, for example, introduces for Danto a new artistically relevant predicate of "ready made," thus adding the predicate "not ready made" to the previous artworks. For a reformulation of Dante's philosophy into a theory, see: Močnik, "U umetnosti, savremenost počinje I9I7." 24

"Representative" is here understood in the widest "Durkheimian" meaning, which also includes "non-representative" symbolic formations (abstraction and alike).
Using the same conceptual apparatus, one can represent the mechanisms of specific scepticism in the contemporary aesthetic ideology. Here, too, the semiotics of the artwork is not constituted until it is complemented by the aesthetic validation of the ideological apparatuses in the cultural sphere. Practices in these cultural-artistic ideological apparatuses are heterogeneous, and so are their products. This heterogeneity arises not only from the differences in the specific historical beginnings and the subsequent rearticulation of the individual apparatuses, ${ }^{20}$ but is immanent to the contemporary aesthetic ideology, which since the proclamation of the disinterestedness of aesthetic practices, their products, and their perception, requires the individuality and, therefore, "plurality" of aesthetic judgments. This liberal aesthetic ideology unifies the otherwise heterogeneous apparatuses into an autonomous artistic-cultural sphere. ${ }^{21}$ Regardless of its possible ideological tendency, an artefact with an artistic claim becomes an artwork by force of the dominant liberal aesthetic ideology, constitutive of the bourgeois cultural-artistic sphere.

Various written and oral presentations of an artefact (criticism, "theories," literary works that refer to it, essays, debates, exhibitions, catalogues, and so on), all the "paper trail" ${ }^{22}$ that the artefact leaves in public, provide the content to the semiotic supplementation that, as the form of the expression, symbolizes the artefact and transforms it into an artwork. At the level of the art-world, the expressions are linked to their contents by the art-system agents' practices, which in accordance with the market tendency to artificially differentiate the products, tend to be mediated by different ideologies, but are unified by the dominant liberal ideology of aesthetic autonomy. This semiotic (and "semiotizing") addition-supplement is linked to the semiotics of the artwork (created retroactively by supplementation) through the apparatuses of aesthetic ideology or the "artworld," as Arthur Danto has romantically named it. ${ }^{23} \mathrm{In}$ the semiotics of an artwork, the whole of the supplement (expression + content) figures as the form of the expression. The supplement transforms the substance of the expression (= artefact) into an element of artistic semiotics that expresses the content with the "representative" ${ }^{24}$ substance and the form determined by the constellation of "artistically relevant predicates." The supplement further suggests the adequate individual reception of the artwork, allowing it to link the content to the form. On the other side, the content has already been linked to the expression by the aesthetic ideology of specific scepticism, shared by cultivated observers.

The semiotics of the contemporary functioning of an artwork can be represented as in Scheme 2.

In the semiotic scheme of aesthetic ideology, there is a pronounced polarization of "apparatuses/individuals" which is absent from magic. In magic, the individual shaman is one among many apparatuses of the dominant ideology, 
dimenzija i uslov njihove dinamike; na polu individue individualna percepcija pak je dinamička i konjunkturna dimenzija, dok je individualno verovanje na način posebnog skepticizma statička, strukturna dimenzija koja je uslov dinamike. ${ }^{25}$ Šemu dakle organizuje još jedna osa, pravougaona na osu „aparati/individue”-osa „struktura (aparati art-sistema + individualna vera) / konjunktura (prakse agenata art sistema + individualna percepcija)". Predstavljeno Šemom 3.

Razliku između magijske i estetske ideološke interpelacije možemo formulisati i ovako: učesnici magijske radnje ne mogu da zamisle alternativnu simbolizaciju, ${ }^{26}$ dok učesnici estetske radnje moraju izmišljati nove alternative. Iz prve situacije proizlazi terapeutski učinak, iz druge estetski učinak.

Pokazali smo dakle: vantržišna motivacija koja od umetničkih dela pravi robe, delo je kulturno-umetničkih ideoloških aparata i njihovih praksi, čiju pluralnost utemeljuje i objedinjuje ideologija umetničke autonomije; ideološka interpelacija estetske ideologije strukturisana je na način posebnog skepticizma koji pluralističko bogatstvo umetničkih praksi i recepcijā unapred uključuje u horizont buržoaske ideologije autonomnih društvenih sfera. Tim mehanizmima obezbeđen je ulaz umetničkih roba na tržište, održavanje njihove robne prirode i njihova eventualna tržišna aprecijacija koja opet zavisi od vanekonomskih faktora.

Potpuna šema vanekonomske motivacije (Šema 3) pokazuje da je ideološki sistem savremene umetnosti sposoban da razrešava protivrečja između reprodukcije strukture i pritisaka konjunkturnih prepleta istorijskih procesa koji mogu potkopavati logiku strukture. Ovu „otpornost” u odnosu na uslove svoje produkcije i dalje istorijske egzistencije savremena umetnost nasledila je od moderne umetnosti, ${ }^{27}$ ali su konkretni mehanizmi te „emancipacije” od društveno-istorijskih procesa sada inverzni nekadašnjim modernim mehanizmima. Dok su u modernoj umetnosti posmatračica i posmatrač slobodno percipirali (i eventualno interpretirali) umetničko delo u okvirima koje im je određivalo samo to delo, kod savremene umetnosti posmatračica i posmatrač treba da sami pronađu okvir u kome će izloženi artefakt funkcionisati kao umetničko delo. Ako im to ne uspeva ili ako ne veruju u svoju kompetenciju, mogu se osloniti na aparate sveta umetnosti. Tako se interpelativna moć aparata hrani interpelativnom nemoći artefakata. Iz toga možemo retroaktivno zaključiti da eventualni „neposredni” estetski perceptivni i interpretativni akt proizlazi od toga što je posmatrač već uspešno interpelisan u mehanizme aparata, ili od toga što su ti mehanizmi već uspešno inkorporisani u artefakt, ili od oboje.

Naša analiza retroaktivno pojašnjava veliku reproduktivnu moć estetske ideologije i njenih aparata, a i njihovu sposobnost da se tvorno povežu sa preovladavajućim procesima epohe od lihvarskih praksi četrnaestog veka do finansijskih špekulacija dvadeset prvog veka.

•

\section{5}

Time je u principu uklonjena dilema „struktura ili akcija” kroz koju se u različitim verzijama ponavljala ishodišna debata između Durkheim-a i Tarde-a. „Struktura” i „konjunktura” su koncepti istog problemskog polja, a koncept interpelacije preko koncepta ideološkog mehanizma ukida dihotomiju „struktura/individua”.

26

„Nije važno da šamanova mitologija ne odgovara objektivnoj stvarnosti: bolesnica u nju vjeruje i član je društva koje u nju vjeruje. Duhovi zaštitnici i zli duhovi, natprirodna čudovišta i magijske životinje pripadaju suvislom sustavu koji utemeljuje urođeničko shvaćanje univerzuma. Bolesnica ih prihvaća ili, tačnije, ona nije nikada u njih posumnjala.” Lévi-Strauss, „Simbolička delotvornost”, 194. 27

Za problematiku moderne estetske ideologije, vidi: Močnik, „Teorija umetnostnih praks". 


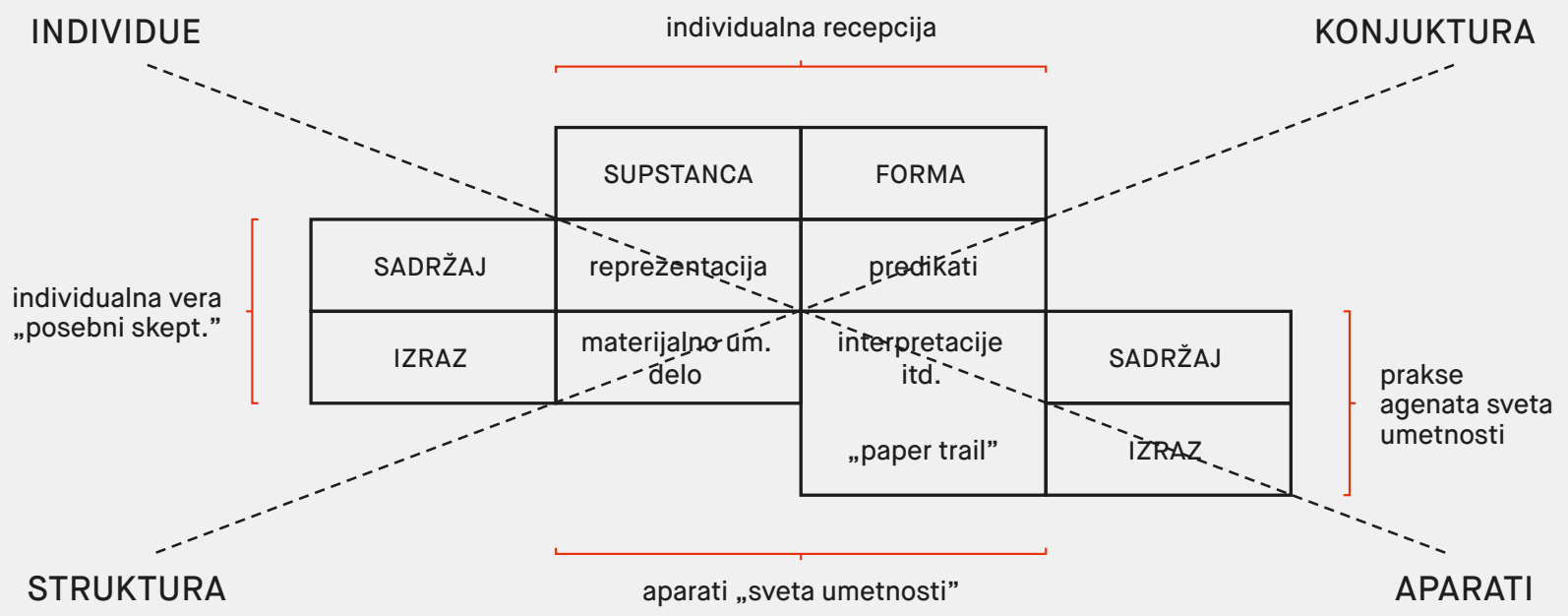




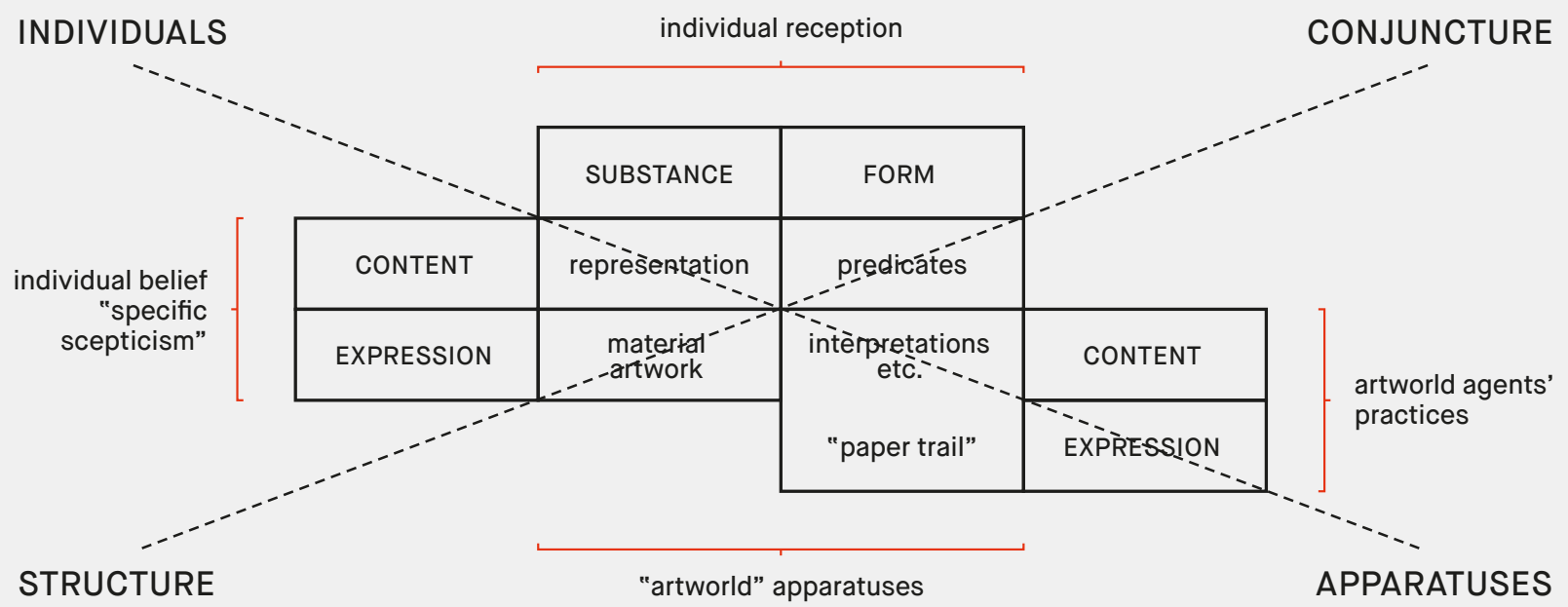


while the individual mental actions of his "patient" are effects of the integration of the childbearing woman into that ideology and its apparatuses. The therapeutic efficiency of individual psychology is triggered only by the shaman's actions. Thus, our schematization of Lévi-Strauss' theory of magic should also be viewed as a schematization of the specific-magical-type of ideological interpellation.

The scheme of aesthetic ideology shows the aesthetic ideological interpellation. In addition to the polarization of “apparatuses/individual," its specificity is the bourgeois ideological pluralism on both poles, and the unifying work of the dominant (aesthetic) ideology. The opposite poles are distributed inversely symmetrically. While the art system agents' practices are the conjunctural, dynamic dimension of the apparatus, the art institutions are their structural, static dimension and the condition of their dynamics. At the pole of the individual, individual perception is the dynamic, conjunctural dimension, while individual belief in the modality of specific scepticism is the static, structural dimension and the condition of the dynamics. ${ }^{25}$ Thus, the scheme is organized along yet another axis, perpendicular to the "apparatuses/individual" axis, the axis "structure (apparatuses of the art system + individual faith) / conjuncture (art system agents' practices + individual perception)."

This can be presented as in Scheme 3.

The difference between magical and aesthetic ideological interpellation can be formulated as follows: the participants of magical action cannot imagine an alternative symbolization, ${ }^{26}$ while the participants of aesthetic action must invent new alternatives. The first situation results in a therapeutic effect, the second in an aesthetic effect.

We have shown that the non-market motivation, which turns artworks into commodities, is the work of cultural-artistic ideological apparatuses and their practices, whose plurality is justified and unified by the ideology of artistic autonomy. In aesthetic ideology, ideological interpellation is structured by the means of specific scepticism, which in advance integrates the pluralistic richness of artistic practices and receptions into the horizon of the bourgeois ideology of autonomous social spheres. These mechanisms secure the entry of

In principle, this eliminates the dilemma of "structure or action" that, in various versions, has been reiterating the initial debate between Durkheim and Tarde. "Structure" and "conjuncture" are concepts of the same problem field, and the concept of interpellation abolishes the "structure/individual" dichotomy through the concept of ideological mechanism.

26

"That the mythology of the shaman does not correspond to an objective reality does not matter. The sick woman believes in the myth and belongs to a society, which believes in it. The tutelary spirits and malevolent spirits, the supernormal monsters and magical animals, are all part of a coherent system on which the native conception of the universe is founded. The sick woman accepts these mythical beings or, more accurately, she has never questioned their existence." LéviStrauss, "The Effectiveness of Symbols," I97.

27

For the problem field of modern aesthetic ideology, see: Močnik, "Teorija umetnostnih praks." artistic commodities upon the market, the maintenance of their commodity nature, and their possible market appreciation, which again depends on non-economic factors.

The complete scheme of non-economic motivation (Scheme 3) shows that the ideological system of contemporary art is capable of resolving contradictions between the reproduction of the structure and the pressures of the conjunctural intertwining of historical processes that may threaten to undermine the logic of the structure. This "resilience" of contemporary art with regard to the conditions of its production and its further historical existence has been inherited from modern art. ${ }^{27}$ However, the specific mechanisms of this "emancipation" from socio- 


\section{POPIS LITERATURE / BIBLIOGRAPHY}

Althusser, Louis. Ideologija i državni ideološki aparati. Sine loco: Karpos, 2009.

. Ideology and Ideological State Apparatuses. Prevod/Translation: G.M. Goshgarian. London/New York: Verso, 2014.

Arrighi, Giovanni. The Long Twentieth Century: Money, Power and the Origins of Our Times. London: Verso, 2010. [1994.]

Bart, Rolan [Barthes, Roland]. Elementi semiologije. Prevod/Translation: Ivan Čolović. Beograd: XX. vek, 2015.

Elements of Semiology. Prevod/Translation: Annette Lavers, Colin Smith. New York: Hill and Wang, 1964.

Breznik, Maja. Kultura danajskih darov [The culture of Danaans' gifts]. Ljubljana: Sophia, 2009.

„General skepticism in the arts”. Primerjalna književnost 2 (2011.): 75-86. Dostupno na/Available at: http://www.dlib.si/details/ URN:NBN:SI:DOC-IAMNRO41 (pristupljeno 29. siječnja 2019./last accessed on January 29, 2019).

Posebni skepticizem v umetnosti [Special scepticism in art]. Ljubljana: Sophia, 2011.

Danto, Arthur. „The Artworld”. The Journal of Philosophy 19 (1964).

Durkheim, Émile, Pravila sociološke metode. Prevod/Translation: Gordana V. Popović. Zagreb: Naklada Jesenski i Turk/HSD, 1999.

The Rules of Sociological Method. Prevod/Translation: W.D. Halls. Basingstoke: Palgrave McMillan, 2013.

Evans-Pritchard, Edward. Witchcraft, Oracles, and Magic among the Azande. Oxford: Oxford UP, 1937.

Hjelmslev, Louis. Prolegomena to a Theory of Language. Prevod/ Translation: Francis J. Whitfield. Madison: University of Wisconsin Press, 1961. [1943.]

Kirn, Gal, Habjan, Jernej, ur./ed. „The Yugoslav Partisan Art”. Slavica Tergestina 17 (2016.) Dostupno na/Available at: https://www.openstarts. units.it/bitstream/10077/13101/1/SlavicaTer_17-2016.pdf (pristupljeno 28. siječnja 2019./last accessed on January 28, 2019).

Lévi-Strauss, Claude. „Vrač i njegova magija” [The Sorcerer and His Magic]. U/In: Strukturalna antropologija. Prevod/Translation: Anđelko Habazin. Zagreb: Stvarnost, 1989.

. „Simbolička delotvornost” [The Effectiveness of Symbols]. U/In: Strukturalna antropologija. Prevod/Translation: Anđelko Habazin. Zagreb: Stvarnost, 1989.

Structural Anthropology. Prevod/Translation: Claire Jacobson, Brooke Grundfest Schoepf. New York: Basic Books, 1963.

Lloyd, Geoffrey E. R. Magic, Reason and Experience: Studies in the Origins and Development of Greek Science. Cambridge: Cambridge UP, 1979.

Miletić, Miloš, Radovanović, Mirjana, ur./ed. Lekcije o odbrani [Lectures on defence]. Beograd: KURS, RLSSEE, 2017. Dostupno na/ Available at: https://www.rosalux.rs/sites/default/files/publications/ LEKCIJE_O_ODBRANI_II_2017_WEB.pdf (pristupljeno 28. siječnja 2019./last accessed on January 28, 2019).

Močnik, Rastko. „Teorija umetnostnih praks” [Theory of art practices], 49-82. U/In: Veselje v gledanju. Ljubljana: Založba /*cf., 2007.
. „U umetnosti, savremenost počinje 1917” [In art, contemporaneity begins in 1917], 53-93. U/In: Nova povezivanja. Od scene do mreže, ur./ed. Jovan Čekić, Miško Šuvaković. Beograd: FMK, 2018. Dostupno na/Available at: http://www.studijesavremenosti.org/wp-content/uploads/2018/04/ novapovezivanja.pdf ili/or: http://www.studijesavremenostiorg/2017/11/11 /u-umetnosti-savremenost-pocinje-1917/ (pristupljeno 28. siječnja 2019./ last accessed on January 28,2019$)$.

Pantić, Rade. „Elitno i popularno u jugoslovenskoj filmskoj kulturi 1945-1965" [Elite and popular in Yugoslav film culture, 1945-1965]. Istorija 20. veka 35/1 (2017.): 103-124.

. „Od kulture u ,socijalizmu' do socijalističke kulture” [From culture in "socialism" to socialist culture], 185-200. U/In: Gradove smo vam podigli. O protivrečnostima jugoslovenskog socijalizma, ur./ed. Vida Knežević, Marko Miletić. Beograd: CZKD, 2018.

„Ka kritici političke ekonomije umetničkog dela” [Towards a critique of the political economy of art]. U/In: Teorija simboličkih formacija, ur./ed. Rade Pantić, Rastko Močnik. Beograd: FMK, 2019 (u pripremi za štampu/in preparation for the press).

Pašukanis, Jevgenij Bronislavovič [Pashukanis, Evgeny B.]. Opšta teorija prava i marksizam. Prevod/Translation: Ljubomir Tadić. Sarajevo: Veselin Masleša, 1958.

The General Theory of Law and Marxism. London/New York. Routledge, 2017. 
historical processes have been inverted with regard to the previous, modern mechanisms. While in modern art the observer freely perceived (and possibly interpreted) the artwork within the framework determined by that particular artwork, in contemporary art it is the observer who must find a framework within which the exhibited artefact will function as an artwork. If he or she does not manage to find a suitable frame, or if they do not trust their competence, they can rely on the apparatuses of the art-world. Thus, the interpellative power of the apparatuses is maintained by the interpellative powerlessness of the artefacts. From this we can retroactively conclude that any possible "immediate" aesthetic act of perception or interpretation comes from the fact that the observer has already been successfully interpellated into the mechanisms of the apparatuses, or from the fact that these mechanisms have already been successfully incorporated into the artefact, or from both.

Our analysis retrospectively explains the great reproductive power of aesthetic ideology and its apparatuses, as well as their ability to be constructively connected to the dominant processes of the epoch-from the fourteenth century usury practices to the financial speculations of the twenty-first century. 